\title{
Fram Strait sea ice export variability and September Arctic sea ice extent over the last 80 years
}

\author{
Lars H. Smedsrud ${ }^{1,2,3}$, Mari H. Halvorsen ${ }^{1}$, Julienne C. Stroeve ${ }^{4,5}$, Rong Zhang ${ }^{6}$, and Kjell Kloster ${ }^{7}$ \\ ${ }^{1}$ Geophysical Institute, University of Bergen, Bergen, Norway \\ ${ }^{2}$ Bjerknes Centre for Climate Research, Bergen, Norway \\ ${ }^{3}$ University Centre in Svalbard, Longyearbyen, Svalbard \\ ${ }^{4}$ National Snow and Ice Data Centre, University of Colorado, Boulder, USA \\ ${ }^{5}$ Centre for Polar Observation and Modelling, University College London, London, UK \\ ${ }^{6}$ Geophysical Fluid Dynamics Laboratory, National Oceanic and Atmospheric Administration, \\ Princeton, New Jersey, USA \\ ${ }^{7}$ Nansen Environmental and Remote Sensing Center, Bergen, Norway \\ Correspondence to: Lars H. Smedsrud (lars.smedsrud@uib.no)
}

Received: 1 April 2016 - Published in The Cryosphere Discuss.: 2 May 2016

Revised: 16 December 2016 - Accepted: 19 December 2016 - Published: 13 January 2017

\begin{abstract}
A new long-term data record of Fram Strait sea ice area export from 1935 to 2014 is developed using a combination of satellite radar images and station observations of surface pressure across Fram Strait. This data record shows that the long-term annual mean export is about $880000 \mathrm{~km}^{2}$, representing $10 \%$ of the sea-ice-covered area inside the basin. The time series has large interannual and multi-decadal variability but no long-term trend. However, during the last decades, the amount of ice exported has increased, with several years having annual ice exports that exceeded 1 million $\mathrm{km}^{2}$. This increase is a result of faster southward ice drift speeds due to stronger southward geostrophic winds, largely explained by increasing surface pressure over Greenland. Evaluating the trend onwards from 1979 reveals an increase in annual ice export of about $+6 \%$ per decade, with spring and summer showing larger changes in ice export $(+11 \%$ per decade $)$ compared to autumn and winter $(+2.6 \%$ per decade). Increased ice export during winter will generally result in new ice growth and contributes to thinning inside the Arctic Basin. Increased ice export during summer or spring will, in contrast, contribute directly to open water further north and a reduced summer sea ice extent through the ice-albedo feedback. Relatively low spring and summer export from 1950 to 1970 is thus consistent with a higher mid-September sea ice extent for these years. Our results are not sensitive to long-term change in Fram Strait sea ice con-
\end{abstract}

centration. We find a general moderate influence between export anomalies and the following September sea ice extent, explaining $18 \%$ of the variance between 1935 and 2014, but with higher values since 2004 .

\section{Introduction}

Along with expectations for a warming planet, the spatial extent of the Arctic sea ice cover has declined. This is especially apparent during the last 2 decades as the Arctic sea ice cover has become both thinner and smaller in extent (Lindsay and Schweiger, 2015; Comiso, 2012; Stroeve et al., 2012). In September 2012, the lowest September sea ice extent (SIE) since the satellite record started in 1979 occurred. The 2012 minimum was $16 \%$ lower than in 2007 , and $44 \%$ below the 1981-2010 average minimum. While the mean September SIE has recovered somewhat after 2012, including summer 2016, the last 10 years have seen the 10 lowest extents on record. A number of processes have been suggested to explain the ice loss, but both observations and simulations from global climate models point to an increasing influence of warming from greenhouse gas forcing as a dominant driver of the observed sea ice loss (Stroeve and Notz, 2015; Kay et al., 2011). Natural variability has also played a role, including increased poleward transport of heat in both the ocean 


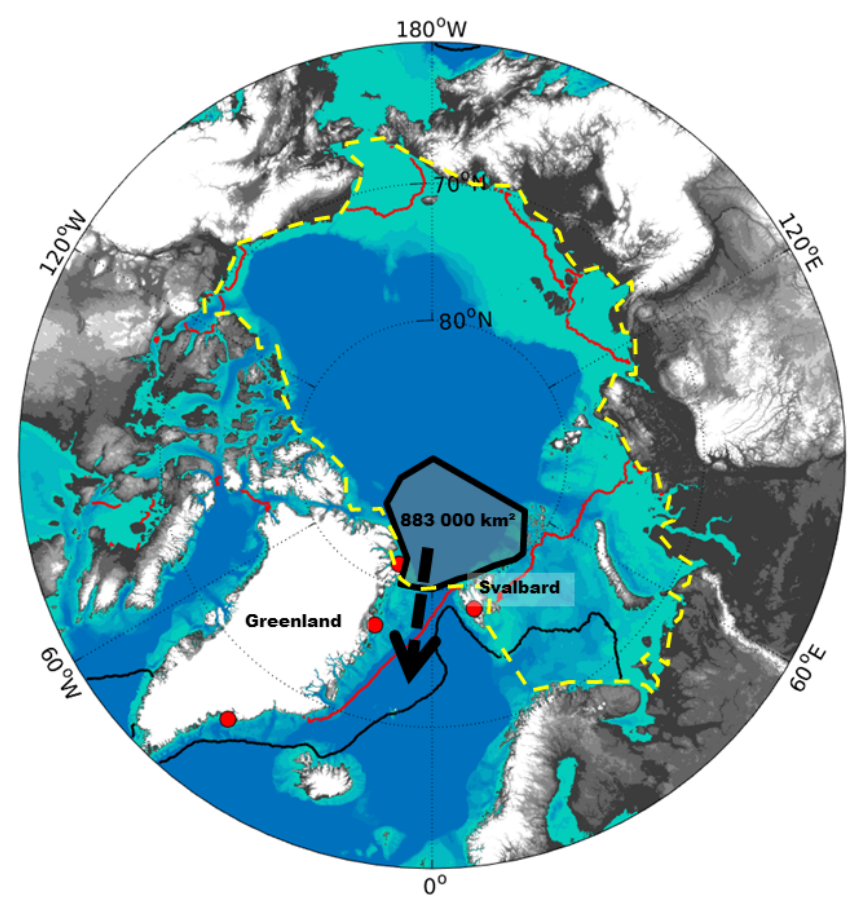

Figure 1. The Arctic Ocean and surrounding shelf and land areas. The large black arrow shows the location of Fram Strait, and the red circles show the positions of the meteorological stations with sea level pressure observations. The 1935-2014 mean positions of the mid-month sea ice extent are plotted for September (red) and March (black). The 1935-2014 mean annually exported sea ice area $\left(883000 \mathrm{~km}^{2}\right)$ is illustrated by the polygon. The outer extent of the Arctic Ocean domain is drawn using the yellow dashed line.

and atmosphere (Graversen et al., 2011; Zhang, 2015), an increase in downwelling long-wave radiation due to cloud cover (Francis et al., 2005), and changes in atmospheric circulation that enhance ice export out of the Arctic (Nghiem et al., 2007; Smedsrud et al., 2011). However, despite the large number of existing studies, the role and influence of natural variability remain unclear, especially on longer timescales than the current satellite data record.

Historically, about $10 \%$ of the Arctic sea ice area is exported through Fram Strait (FS) annually (Fig. 1), and the ice export through the other Arctic gateways is an order of magnitude smaller (Kwok, 2009). Because quite thick ice is lost by this export through FS (Hansen et al., 2013), a larger than normal ice export will decrease the remaining mean thickness within the Arctic Basin. An influence of export anomalies on Arctic sea ice thickness was previously suggested by Rigor et al. (2002) using buoy data. A similar conclusion was reached using model simulations from climate models participating in the Coupled Model Intercomparison Project Phase 5 (CMIP5) (Langehaug et al., 2013). Recently Fučkar et al. (2015) found that much of the northern hemispheric sea ice thickness variability could be explained by changes in sea ice motion related to wind forcing.
Several studies have suggested that sea ice drift speeds are increasing, both within the Arctic Basin (Hakkinen et al., 2008; Rampal et al., 2009) and in FS (Rampal et al., 2009; Smedsrud et al., 2011). Positive trends were also found in the annual FS ice area export by Widell et al. (2003) (4\% per decade from 1950 to 2000) and Smedsrud et al. (2011) (5\% per decade from 1957 to 2010). Using the available NSIDC sea ice drift data, Krumpen et al. (2016) recently found a much higher trend for 1980-2012 (37.6\% per decade) but noted that the large positive trend seemed "unrealistic". However, contrary to these studies, Kwok et al. (2013) found a small negative trend in annual FS ice area export between 1982 and 2009, but with positive trends for 2001-2009 for both annual (October-September) and summer (June-September). Spreen et al. (2009) did not observe any significant change in FS ice volume export for the period 2003-2008 for observed winter means (October-April). Thus, some uncertainty remains on how FS ice export has changed and how it has influenced the long-term decline in the summer ice cover.

The Arctic seasonal maximum sea ice cover generally occurs in late February or early March (Zwally and Gloersen, 2008 ), though it has also been observed to occur as late as early April (e.g., on 2 April in 2010; https://nsidc.org/ arcticseaicenews/2010/04). Changes in ice export through FS between March and August could therefore influence the following September SIE by fostering development of open water within the ice pack that in turn enhances the ice-albedo feedback during the melt season (Smedsrud et al., 2011; Kwok and Cunningham, 2010). Such an influence has recently been examined between 1993 and 2012 by Williams et al. (2016) in combination with coastal divergence. This study suggested that Fram Strait ice area export is a good predictor for the September sea ice extent because it represents the sum of ice export from the peripheral seas and the net pack ice divergence. This study expands on the work by Williams et al. (2016) by estimating the FS ice area export over a much longer time period, from 1935 to 2014. In this study, we evaluate the long-term mean, variability, and trends over this 80 -year record and further examine the influence of the long-term FS export on a new time series of September SIE, also covering the years 1935-2014 (Walsh et al., 2015).

\section{Data and methods}

In this study we rely on a combination of ice drift speeds estimated from Envisat Advanced Synthetic Aperture Radar (ASAR) WideSwath and Radarsat-2 ScanSAR (from 2012) images and monthly mean sea level pressure (mSLP) differences across Fram Strait to construct a long-term data record of FS ice export. 


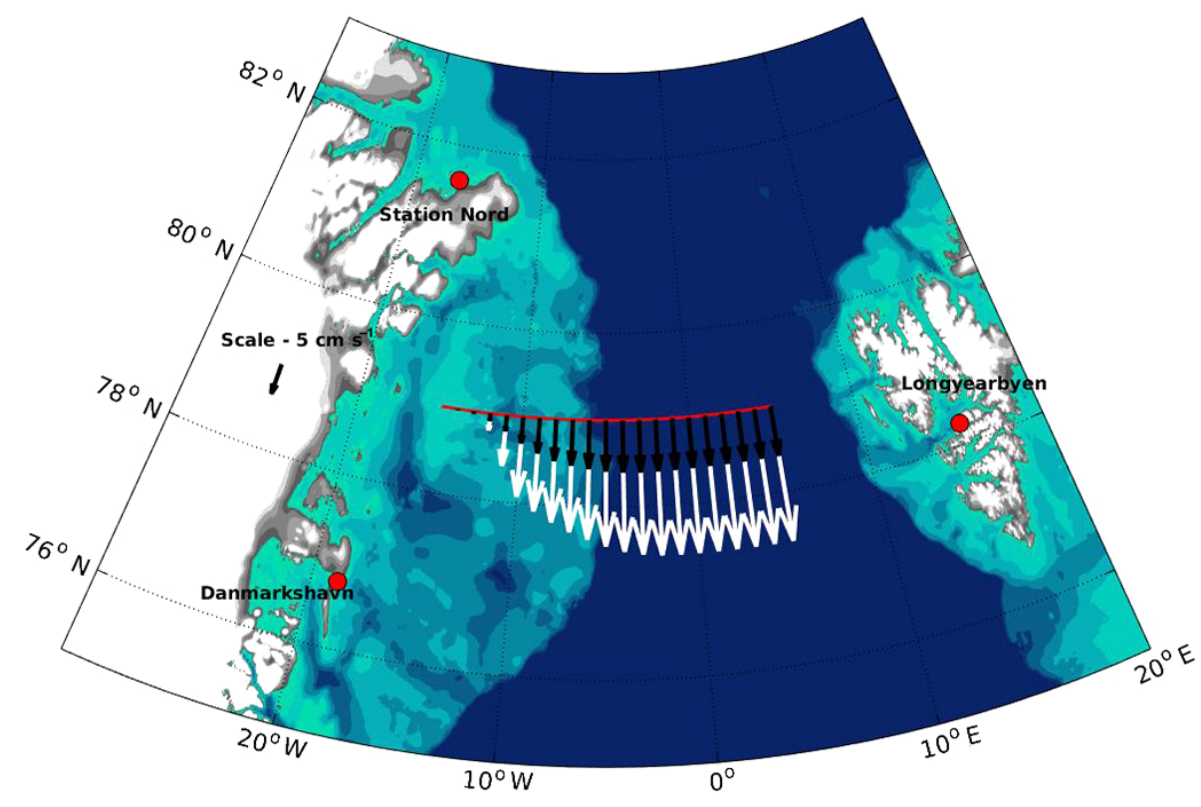

Figure 2. The Fram Strait between Greenland (left) and Svalbard (right) with summer (black arrows) and winter (white arrows) mean sea ice drift speed. Southward ice drift across $79^{\circ} \mathrm{N}$ (red line) from February 2004 to December 2014 were interpolated to $1^{\circ}$ bins based on SAR imagery. Summer speeds are June-September means, while winter speeds are December-March means. Shades of blue show ocean bathymetry in $100 \mathrm{~m}$ steps down to $500 \mathrm{~m}$ depth. Red circles show locations for surface pressure observations on Svalbard (Longyearbyen) and Greenland (Station Nord and Danmarkshavn). Pressure observations were interpolated between the Greenland stations to calculate the mean pressure gradient along $78.25^{\circ} \mathrm{N}$. Before 1958 pressure observations from Danmarkshavn are lacking, so observations from Tasiilaq $\left(65.60^{\circ} \mathrm{N}, 37.63^{\circ} \mathrm{W}\right)$ were used, further south along the Greenland coast (Fig. 1).

\subsection{Ice drift observations: 2004-2014}

We use observed sea ice drift speeds onwards from February 2004 and updated through December 2014, calculated by recognizing displacement vectors manually on ASAR WideSwath and Radarsat-2 ScanSAR images captured 3 days apart (Kloster and Sandven, 2015). These images were resampled from 50 to 100 to $300-500 \mathrm{~m}$ pixels in order to reduce the SAR speckle noise, greatly improving feature recognition and tracking accuracy over the 3-day time interval. Displacement vectors that cross $79^{\circ} \mathrm{N}$ were linearly interpolated to bins $\left(1^{\circ}\right.$ longitude, each $\left.21 \mathrm{~km}\right)$ from $15^{\circ} \mathrm{W}$ to $5^{\circ} \mathrm{E}$ (Fig. 2).

For most 3-day image pairs, displacement vectors with an accuracy of $\pm 2 \mathrm{~km}$ and spacing of $30-50 \mathrm{~km}$ were calculated using the known satellite orbit and one reference point. Drifting platforms and buoys were used to estimate uncertainties, indicating values better than $\pm 3 \%$. This accuracy is considered sufficient because subsequent averaging or addition in time-space of many unbiased vectors will generally result in improved accuracy. We calculated mean cross-strait ice drift speed values, defined as the spatial-temporal mean southward speed of all ice crossing $79^{\circ} \mathrm{N}$ (Fig. 1) between the fast ice edge and the pack ice edge at $50 \%$ sea ice concentration. On the western side of the strait, a linear interpolation from zero motion in the stable fast ice to the first measured mo- tion vector was made. It was assumed that ice displacement to the east of the last measured vector is constant near the ice edge. The monthly mean speed value results from the averaging of about 50 individual, unbiased displacement vectors, and thus the calculated mean speed value should have an accuracy better than $\pm 0.1 \mathrm{~cm} \mathrm{~s}^{-1}$.

Using the 3-day mean drift speeds as derived above, corresponding FS ice area export along $79^{\circ} \mathrm{N}$ was calculated as the product of this sea ice drift and corresponding 3-day values of passive microwave sea ice concentration (Kloster and Sandven, 2015). The combined uncertainty of the passive microwave sea ice concentration and ice speed is about $\pm 5 \%$ in the 3-day fluxes. The monthly mean values from 2004 to 2014 are shown in Fig. 3. Values are summarized over a month or a season here (cumulative values) and the uncertainty for these values are further reduced because uncertainties become lower with a larger number of samples. A spring ice area export value of $500000 \mathrm{~km}^{2}$ is the sum of 60 3-day values from 1 March to 31 August and has an estimated uncertainty better than $\pm 5000 \mathrm{~km}^{2}$. From here on, ice area export will be referred to as ice export.

\subsection{Sea level pressure observations: 1935-2014}

To extend the time period, observed monthly mSLP values were used onwards from 1935 to estimate ice export prior 


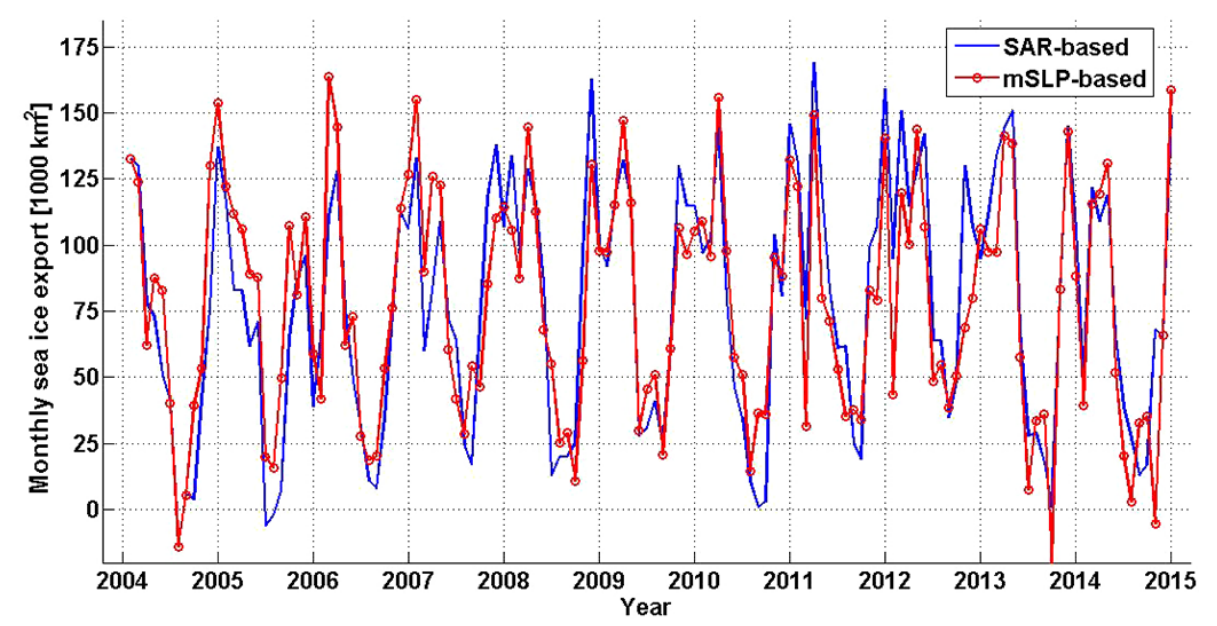

Figure 3. Monthly mean Fram Strait sea ice export. The SAR-based values are calculated from 3-day displacement vectors and corresponding sea ice concentration, while the other time series uses observed mean sea level pressure (mSLP) and the seasonal correction for a stronger East Greenland current during winter.

to the ASAR data starting in February 2004. The cross-strait difference along $78^{\circ} \mathrm{N}$ was calculated between $18^{\circ} \mathrm{W}$ and $15^{\circ} \mathrm{E}$ based on monthly mSLP observations from Longyearbyen (Fig. 2, Svalbard Airport, Norwegian Meteorological Institute, http://eklima.met.no) and from weighted averages of monthly mSLP from two nearby stations on the Greenland side at $18^{\circ} \mathrm{W}$ : Danmarkshavn and Nord (Fig. 2, Danish Meteorological Institute, Cappelen, 2014). mSLP is available from Danmarkshavn and Nord back to 1958. For the 19351958 period, a linear regression between Nord and Tasiilaq further south was performed.

The mSLP observations were then used to calculate crossstrait geostrophic winds following Thorndike and Colony (1982). Because mSLP from Danmarkshavn and Nord correlated well $(r=0.93)$, we derived a linearly interpolated value at $78^{\circ} \mathrm{N}, 18^{\circ} \mathrm{W}$ directly using these stations onwards from 1958. For the period 1935-1958, interpolated values between station Nord and Tasiilaq were used, which have a somewhat lower correlation $(r=0.77)$. Our method assumes that wind and ocean drag are the dominant forces acting on the sea ice, consistent with geostrophic winds explaining more than $70 \%$ of the variance of ice drift speed in the Arctic Ocean (Thorndike and Colony, 1982). In the FS, winds have also been found to be the dominant force acting on sea ice (Widell et al., 2003), and the cross-strait pressure difference in SLP well represents the ice drift on a daily timescale (Tsukernik et al., 2010). However, van Angelen et al. (2011) simulated local Fram Strait surface winds and found them more related to thermal wind forcing than larger-scale forcing. Nevertheless, they found that ice export for individual years from 1979 to 2007 was better explained by large-scale forcing because thermal winds were mostly constant between years.

\subsection{Merged ice drift and export: 1935-2014}

We next evaluate the relationship between the observed SAR ice drift speed and the geostrophic wind since 2004 to verify the use of mSLP to extend the record prior to 2004. A linear regression between monthly mean ice drift speed and geostrophic wind from 2004 to 2014 ( $r=0.77$, with $95 \%$ confidence interval $[0.68,0.83])$ reveals that the ice in FS generally drifts at a speed that is $1.6 \%$ of the geostrophic wind speed (Eq. 1). The constant contribution resulting from the linear regression represents the speed of the ice given no local wind forcing and is $6.7 \mathrm{~cm} \mathrm{~s}^{-1}$ (Eq. 1). In other words, the value of $6.7 \mathrm{~cm} \mathrm{~s}^{-1}$ represents the mean ocean current, though nonlinear components of ice drift, including forces from variations in ocean currents or internal ice stress, may also represent parts of this constant (Thorndike and Colony, 1982). It is important to note, however, that it is not the locally wind-driven ocean current. Both the mean drift speed and the mean ocean current are comparable to previous studies (Widell et al., 2003; Smedsrud et al., 2011; Thorndike and Colony, 1982). The standard error of the regression is $3.4 \mathrm{~cm} \mathrm{~s}^{-1}$.

$V_{\text {ice }}=0.016 \times V_{\mathrm{g}}+0.067\left(\mathrm{~m} \mathrm{~s}^{-1}\right)$

If sea ice concentration does not change systematically inside the ice pack locally, we expect a similar relationship between mSLP and sea ice export. This was indeed what we found, with a correlation between the cross-strait mSLP and ice export of $r=0.73$.

The annual cycle of ice speed and export is similar to earlier estimates, with higher speeds during winter and weaker during summer (Kwok, 2009). The annual mean speed is close to $12 \mathrm{~cm} \mathrm{~s}^{-1}$ (Fig. 4), which is a spatially averaged value between 15 and $5^{\circ} \mathrm{W}$, and a temporal average for the years 2004-2014. 


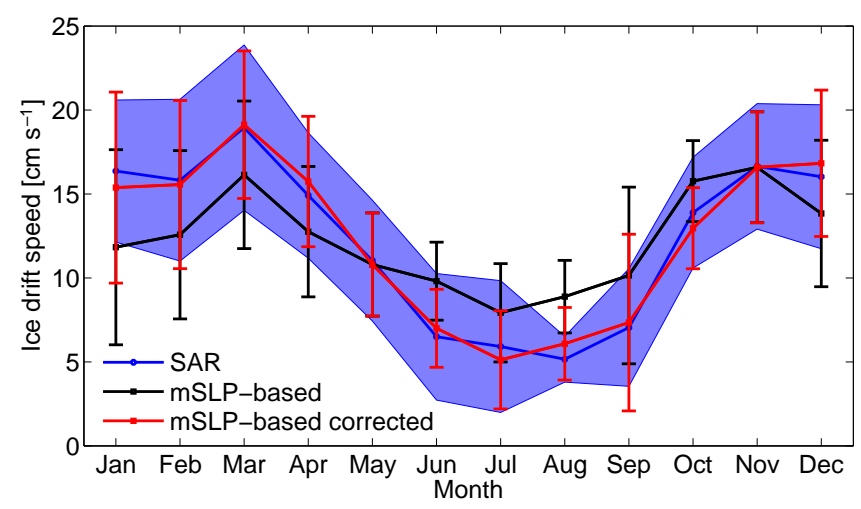

Figure 4. Annual cycle of monthly mean southward ice drift speed in Fram Strait between 2004 and 2014. Observed ice drift speed (SAR) are shown in blue, and our pressure-based ice drift speed in black. The corrected ice drift speed is shown in red. Standard deviations of observed ice drift speed are shaded in purple, and those of calculated ice drift speed as vertical colored lines.

However, a clear seasonal difference is observed between the SAR ice speed and the mSLP-estimated ice speed (Fig. 4). Previously it was assumed that the mean ocean current would be constant throughout the year (Kwok, 2009; Smedsrud et al., 2011), e.g., $6.7 \mathrm{~cm} \mathrm{~s}^{-1}$ from Eq. (1). However, based on the 10 years of detailed SAR velocities, we instead find it is necessary to account for the seasonality of the mean ocean current in order to match the mSLP-derived ice drift with the SAR data. The suggested seasonal change is a mean winter current (December-April) of $9.5 \mathrm{~cm} \mathrm{~s}^{-1}$ and a mean summer current of $3.9 \mathrm{~cm} \mathrm{~s}^{-1}$ (June-October). The East Greenland Current (EGC) thus appears $2.8 \mathrm{~cm} \mathrm{~s}^{-1}$ stronger than the mean during winter and $2.8 \mathrm{~cm} \mathrm{~s}^{-1}$ weaker during summer. Note that this seasonal difference cannot be explained by a seasonally varying internal ice stress, because ice is thicker and denser during winter, which would result in a larger ice stress and therefore weaker ice drift speed for a similar wind speed.

An increase in the EGC would be consistent with generally stronger winds in the North Atlantic region during winter, as well as stronger thermal forcing (van Angelen et al., 2011). This suggests that the EGC is responding to the largerscale wind forcing as well as to the local winds. Generally, the entire circulation along the continental slope of the Arctic Basin-Nordic seas is driven by the wind stress curl north of the Greenland-Scotland ridge (Isachsen et al., 2003). Two recent studies confirm that the EGC is stronger during winter, and may respond to the large-scale wind stress curl in the Nordic Seas or the stronger thermal forcing during winter. It is thus likely that this increase is causing the additional winter export (Fig. 4). De Steur et al. (2014) analyzed mooring data along $79^{\circ} \mathrm{N}$ between 1997 and 2009 and found that surface currents were below $5 \mathrm{~cm} \mathrm{~s}^{-1}$ during summer and 10 $15 \mathrm{~cm} \mathrm{~s}^{-1}$ during winter, also varying in the east-west direc- tion. Daniault et al. (2011) found a maximum in the flow in January and a minimum in July for the years 1992-2009 based on satellite radar altimetry data at $60^{\circ} \mathrm{N}$ and that the vertical distribution remained constant over this time period.

The above studies support a bias correction for the constant EGC speed in Eq. (1) to increase (decrease) the mSLPbased winter (summer) ice speeds. Thus, assuming a stronger EGC during winter, and weaker during summer, we added the seasonal difference to the time series of mSLP-based ice speed. This means that in Eq. (1), we add $2.8 \mathrm{~cm} \mathrm{~s}^{-1}$ to the constant $6.7 \mathrm{~cm} \mathrm{~s}^{-1}$ for the months December through April, and subtract $2.8 \mathrm{~cm} \mathrm{~s}^{-1}$ from the constant $6.7 \mathrm{~cm} \mathrm{~s}^{-1}$ for June through October, while May and November remained unchanged. This bias-corrected mSLP-based ice speed better matches the SAR observations (Fig. 4), with a correlation of $r=0.88$.

The same correction was also applied for the calculated ice export, representing a decrease in summer values of $23800 \mathrm{~km}^{2}$ and increase in winter values of $22400 \mathrm{~km}^{2}$ accordingly (not shown). The seasonal correction further improves the correlations between observed and mSLP-based ice export $(r=0.87)$. Figure 3 compares the mSLP-based and SAR-based monthly mean ice export values between 2004 and 2014 and confirms the close agreement between them. The mSLP-based time series slightly over and underestimates the observed SAR-based values for individual months, but there is no systematic difference over time.

In other words, we expect our bias-corrected mSLP-based time series from 1935 to 2004 to explain about $80 \%$ of the "true" ice drift and export variability. Note that we have assumed a constant seasonality for this bias correction and that if changes in seasonality for ice drift exist prior to 2004 exist this would affect our results. Using high-resolution wind simulation, van Angelen et al. (2011) found a similar correlation $(r=0.85)$ between annual export and surface wind for 1979-2007. Our described seasonal correction is also consistent with their simulated stronger thermal forcing during winter that would set up a sea surface gradient and drive a related stronger barotropic ocean current.

Taking into account the seasonally varying EGC and thermal wind explained above, in addition to the monthly varying geostrophic winds based on observed mSLP, we calculate monthly mean ice export prior to 2004 and merge them with the SAR-based observed ice export from 2004 to 2014. This generates an 80-year-long record of monthly mean FS ice export.

\subsection{Sea ice extent}

Finally, a newly blended historical and modern record of sea ice concentrations is now available from the National Snow and Ice Data Center (NSIDC), the "Gridded monthly sea ice extent and concentration, 1850 onwards" (Walsh et al., 2015). This data set is an improvement upon an earlier historical record from Chapman and Walsh (1991) and pro- 


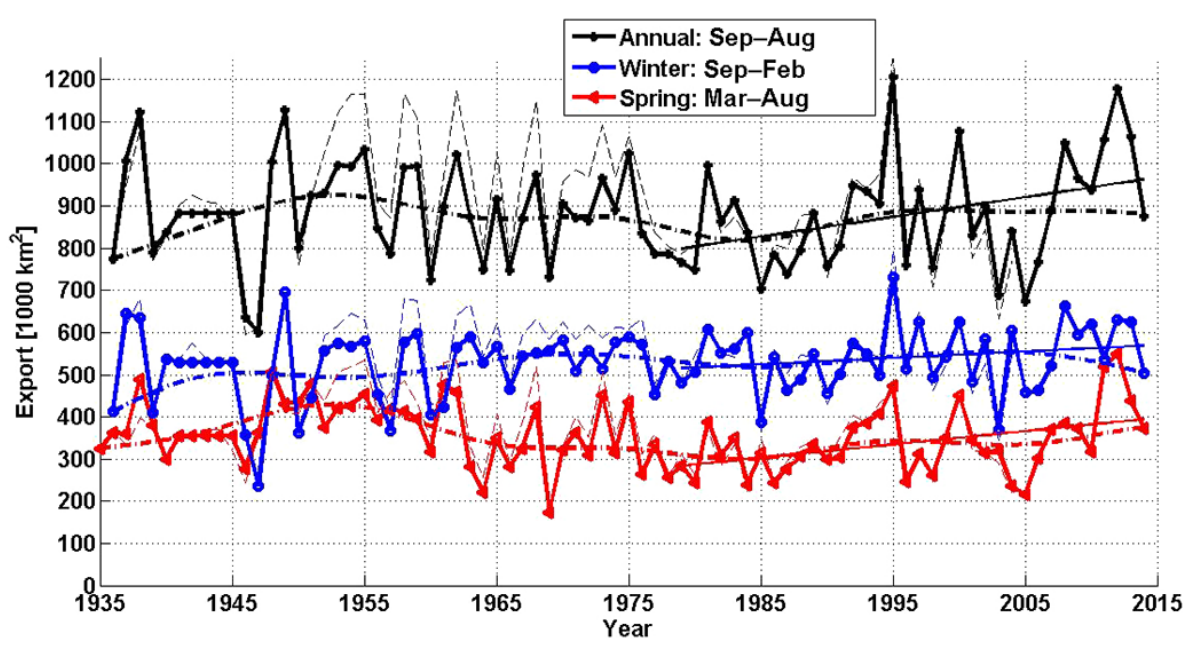

Figure 5. Southward ice area export in Fram Strait. Ice export from 1935 to 2003 is based on the relationship between observed mean sea level pressure and observed ice export by SAR, and ice export from 2004 to 2014 is solely the observations by SAR. Annual values (black) are averaged for 1 September through 31 August. Winter export is 1 September-28 February (blue) and Spring is 1 March-31 August (red). Values are plotted half way through the respective period. Smoothed time series are included produced by filtering with a 20 -year-cutoff eighth-order Butterworth filter (thick dash-dotted lines), and linear trends are plotted onwards from 1979. The long-term (1935-2014) trends are not included because they are not significantly different from zero. The effect of using a time-varying seasonal sea ice concentration based on Walsh et al. (2015) is shown using thin dashed lines.

vides mid-month sea ice concentrations on a $0.25 \times 0.25^{\circ}$ grid (Walsh et al., 2017). A total of 16 different sources of information were used to construct ice cover information back to 1850 . Prior to the modern satellite data record, which began in October 1978 from a series of successive passive microwave sensors (e.g., the Scanning Multichannel Microwave Radiometer (SMMR) and several Special Sensor Microwave/Imager (SSM/I) and SSMIS sensors), observations come from earlier satellite missions, aircraft and ship observations, compilations by naval oceanographers, ice charts from national ice services, and whaling log records, among others. For many regions and time periods several sources of sea ice data and weighting was applied (Walsh et al., 2017). The monthly files are intended to represent ice on the 15 or 16 of each month using the NASA Team sea ice algorithm. Using this data set, the ice extent is defined as the area covered by ice of greater than $15 \%$ ice concentration.

Initial evaluation of the data set indicated a problem with inconsistencies in the land mask applied throughout the entire time period. This was fixed and led to a slight reduction in the overall sea ice extent prior to the satellite data record. To evaluate how ice export influences changes in sea ice cover within the Arctic Basin, we use an Arctic Ocean domain mask as defined in Serreze et al. (2007) and compute sea ice extent within this domain only (Fig. 1). For the September SIE time series this mainly excluded the Greenland Sea downstream of the FS ice export, where we expect high export to contribute to a larger ice cover.

The mid-month sea ice concentration from Walsh et al. (2015) along $79^{\circ} \mathrm{N}\left(15^{\circ} \mathrm{W}\right.$ to $\left.5^{\circ} \mathrm{E}\right)$ was also used to ex- amine the influence of changing sea ice concentration on the spring and winter FS ice export (Fig. 5). This influence is overall smaller than $\pm 10 \%$, and onwards from 1979 no significant differences are visible. We have chosen to present ice export based solely on the station-based daily SLP observations producing the monthly mean mSLP, as further discussed below.

\section{Results}

\subsection{Long-term (1935-2014) annual mean ice export variability and trends}

Figure 2 shows that the temporal mean ice drift speed is quite constant spatially across the FS eastward of $5^{\circ} \mathrm{W}$ and that the speed decreases westward towards the Greenland coast. Velocities are clearly strongest during winter with mean speeds above $20 \mathrm{~cm} \mathrm{~s}^{-1}$, decreasing to less than $10 \mathrm{~cm} \mathrm{~s}^{-1}$ during summer eastward of $5^{\circ} \mathrm{W}$. FS ice drift is in the southsouthwesterly direction steered by the Greenland Coast. The ice export occurs mostly between $5^{\circ} \mathrm{W}$ and the Greenwich meridian. The export is limited on the western side by the decreasing ice speed, reaching zero at $16^{\circ} \mathrm{W}$, where stationary land fast ice is usually found. On the eastern side the ice export is limited by zero concentration, varying from $5^{\circ} \mathrm{W}$ to $5^{\circ} \mathrm{E}$ (not shown).

The 1935-2014 long-term annual FS sea ice export, defined as 1 September to 31 August, is on average $883000 \mathrm{~km}^{2}$ and ranges from 0.6 to 1.2 million km² (Fig. 5). Winter export is defined as September through February and 
has a long-term mean of $528000 \mathrm{~km}^{2}$. We define spring export as March through August, and the mean value is $354000 \mathrm{~km}^{2}$. Note that the 1935-2014 long-term annual mean ice export of $883000 \mathrm{~km}^{2}$ is $25 \%$ higher than previously found by Kwok (2009) using data from 1979 to 2007 , but similar to values from Thorndike and Colony (1984) and Widell et al. (2003) for 1950-2000 and Smedsrud et al. (2011) for the period 1957-2011.

The consequences of the export variability are discussed later; here we just note that since 2006 ice export has remained higher than the long-term mean (Fig. 5) and that for 2011-2013 the annual export exceeded 1 million $\mathrm{km}^{2}$. In addition, there are a number of notable export events in the 80 -year time series. Note that there are no mSLP values observed during World War II, so the seemingly constant values from 1940 to 1945 are set identically to the long-term mean annual values. The lowest annual export occurred in 1946 with only $599000 \mathrm{~km}^{2}$ exported, and the highest export with $1206000 \mathrm{~km}^{2}$ was in 1995 .

The annual and seasonal trends appear robust, and no systematic difference appears by merging the mSLP-based values prior to 2004 with the SAR-based values since 2004. This was confirmed by comparing trends for the merged time series (1935-2014) with those based on the observed mSLP only (1935-2014). For example, the mSLP-based annual trend is 0.2 versus $0.3 \%$ per decade for the merged values, while for winter the values are 1.1 versus $1.6 \%$ per decade and for spring -0.8 versus $-1.3 \%$ per decade. These long-term trends are small and not significantly different from zero $(p=0.2)$, and they are therefore not included in Fig. 5. We also searched for specific cycles, or frequencies, in the new 80-year time series. Apart from the obvious annual cycle (Fig. 4) we could not find any special peaks in calculated spectrums of the annual, winter, or spring export (not shown). The smoothed time series appeared similar for cutoff frequencies representing cycles above 10 years, so we chose to show a 20-year cutoff (or frequency of 0.05 cycles $\mathrm{yr}^{-1}$ ) in Fig. 5. Overall the variations are similar for the annual and spring export values, while there is less long-term variability in the winter export. For the smoothed series there is a distinct peak in annual and spring export between 1951 and 1954. After 1954, there is a decrease in annual and spring export until the mid-1980s, and an overall increase onwards to 2014. Thus, there is a hint of a long-term multidecadal oscillation with a period around 70 years.

\subsection{Recent (1979-2014) ice export variability and trends}

The increasing exports onwards from the 1980s create statistically significant positive trends for both the annual and seasonal values over the modern satellite data record and the time period for which large declines in sea ice have been observed. For example, from 1979 to 2014 we find a positive trend in annual export of $+5.9 \%(p=0.025)$ per decade
(Fig. 5). This trend is consistent with a general increase in ice drift speed observed well inside the deep Arctic Basin (Fig. 1, Spreen et al., 2011; Rampal et al., 2009), but the small number of buoys exiting in FS have precluded estimating trends there. The positive trend in annual ice export from 1979 to 2014 is largely driven by higher ice export during spring: the winter ice export trend is $+3.0 \%(p=0.213)$ per decade, while the spring export trend is $+11.1 \%(p=0.011)$ per decade (Fig. 5).

The increasing spring export since 1979 may have important implications for the sea ice cover, and we therefore analyze this time period further to make sure no biases are introduced by using the merged $\mathrm{mSLP}+$ SAR export fields. Trends are found to be similar between the merged $(\mathrm{mSLP}+\mathrm{SAR})$ and mSLP-based time series, caused by the very similar monthly values between 2004 and 2014 (Fig. 3). There is a positive trend in spring export of $13.1 \%( \pm 6.8)$ per decade from the mSLP-based estimates and a trend of $11.1 \%$ $( \pm 8.1)$ per decade using the merged time series. These trends are not significantly different at the $95 \%$ confidence level. Note that, around 1980, the spring export was approximately half of the winter export. The robust trend in spring export since 1980 has resulted in a smaller seasonal difference, and for 2011 and 2012 the export in winter and spring were of similar magnitude (Fig. 5). The recent high values could perhaps be surprising, were it not for the longer time series where a similar high spring export is evident in the 1950s.

We also do not find a "shift" in the trends after 2004 when the SAR values are used. For example, the spring 19792003 trend is $+9.1 \%( \pm 11.3)$ per decade, almost as high as the $11.1 \%$ for the $1979-2014$ period. So the spring export is the main cause of increased annual export before and after 2003, and the differences are not significant at the $95 \%$ confidence level. Due to the few years and large variability, the $\sim 20$-year trends are generally not significantly different from zero $(p>0.05)$. The annual trend for 1979-2003 is $3.8 \%(p=0.36)$, compared to $5.9 \%$ for $1979-2014$, and for winter $0.8 \%(p=0.84)$, compared to $2.6 \%$ for $1979-2014$. This indicates that the export trends since 1979 are related to a gradual increase in mSLP across FS over most of this period. The increased spring ice export is due to stronger geostrophic winds, driven by an increase of $0.53 \mathrm{hPa}$ per decade in mSLP over Greenland between 1979 and 2014. The increase in SLP is strongest in June-August and covers the larger part of Greenland (not shown). The mSLP trend on the Svalbard side is a slightly lower and negative trend, is strongest in March-May, and covers the larger part of the Barents Sea (not shown).

\section{Discussion}

In this study we use station mSLP data, rather than values derived from atmospheric reanalysis data sets and simulations (Smedsrud et al., 2011; Widell et al., 2003; van Ange- 


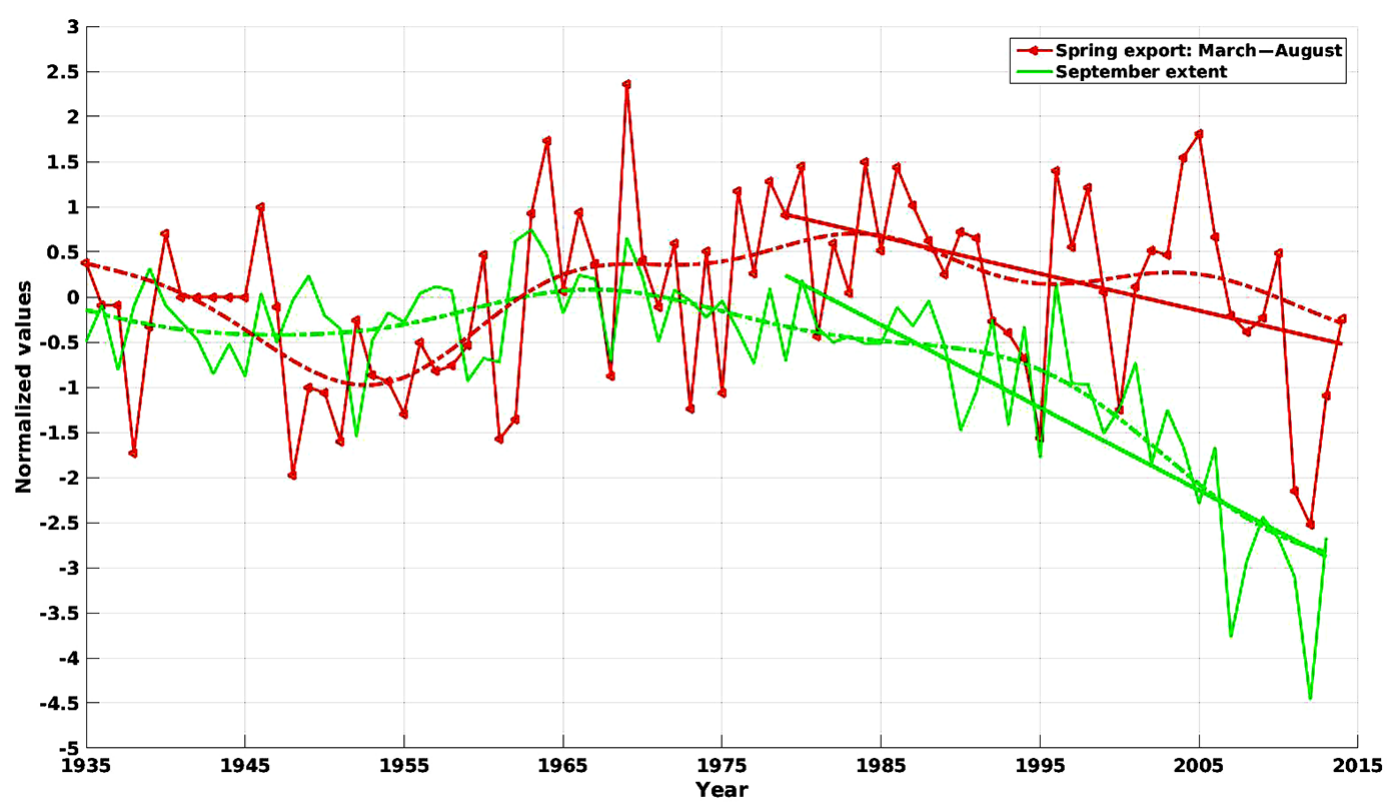

Figure 6. Spring Fram Strait ice area export (red) and mid-September Arctic SIE (green). The ice export is averaged for March 1st through 31 August. Both time series have been normalized by subtracting the mean and dividing with the standard deviation. The ice export is here plotted with negative values as high southward export for easier comparison. Smoothed time series are included, produced by filtering with a 20-year-cutoff eighth-order Butterworth filter. The 1979-2014 trends in ice export and mid-September SIE are shown as solid straight lines. SIE values are obtained from Walsh et al. (2015).

len et al., 2011), because we discovered unexplained systematic differences between NCEP reanalysis MSLP fields and observed mSLP within the FS in recent years. Despite the wide use of reanalysis data sets, they are heavily influenced by the numerical model used to simulate the fields, and they are therefore regarded as less accurate than the station data used in this study.

Prior to 2004 we do not utilize observations of cross-strait variations in the width of the ice-covered area, ice speed, or ice concentrations, but base our ice export values solely on the regression equation found between observed mSLP from Longyearbyen, station Nord, Danmarkshavn, and Tasiilaq (Fig. 2) and observed SAR ice export. The new Walsh et al. (2015) mid-month sea ice concentration provided a possibility to consistently analyze the effect of varying seasonal sea ice concentration prior to 2004 (Fig. 5). The changes were overall small, and only during the 1950 s were sea ice concentration anomalies across $79^{\circ} \mathrm{N}\left(15^{\circ} \mathrm{W}-5^{\circ} \mathrm{E}\right)$ large enough to contribute to a $10 \%$ increase in ice export (Fig. 5).

The 1935-2013 seasonal mean ice concentration from Walsh et al. (2015) during winter is $83 \%$ (standard deviation of $\pm 11 \%$ ) and for spring is close to $72 \%$ (standard deviation of $\pm 9 \%$, not shown). There are no significant longterm trends in sea ice concentration for the spring or winter months between 1935 and 2013. We concluded that using mSLP based on daily observations is the most consistent way to calculate ice export over the last 80 years. The Walsh et al. (2015) values are mid-month values mostly based on sea ice extent estimates during summer before 1979, with very few winter observations available.

There are other possible systematic contributions to the overall uncertainty from a number of factors, like sea ice roughness, the ocean current, the thermal wind, and changes in sea ice thickness. Our best estimate for the uncertainty in the seasonal spring and winter means is therefore about $10 \%$, i.e., $354000 \mathrm{~km}^{2} \pm 35000 \mathrm{~km}^{2}$ for spring and $528000 \mathrm{~km}^{2} \pm 52000 \mathrm{~km}^{2}$ for winter.

\subsection{Long-term variability of September SIE}

The mid-September SIE time series shows two stages, a modest increase from 1935 until around 1965 and then a monotonic decrease over the last 50 years (Fig. 6). There is a "break point" around the mid-1990s when the September SIE loss accelerates as has been noted earlier (Stroeve et al., 2012). From the mid-1960s until the mid-1990s the loss in SIE is small. The minimum SIE value predating 1995 occurs in 1952, and the last two minima in 2007 and 2012 are also clearly visible (Fig. 6). The overall mid-September SIE maximum occurred in 1963.

Evaluating 30-year trends for successive 30-year periods, along with the standard errors, shows distinct periods of ice loss and ice gain (Fig. 7). From the 1950s to 1967, trends are positive and then become negative. The long-term 19351990 trend is essentially 0 , in stark contrast to the 1991 to 2013 trend, which is strongly negative. The last seven con- 


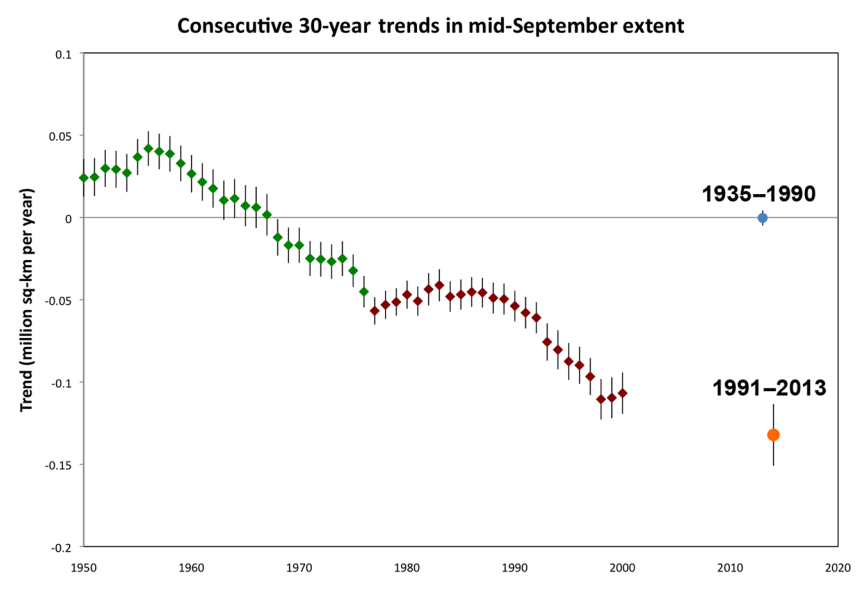

Figure 7. Consecutive 30-year trends of mid-September SIE in the Arctic Basin. The first green symbol shows the 30-year trend between 1935 and 1964 and is plotted at the center year in 1950. The next value in 1951 shows the trend for 1936-1965, and so on. The last green symbol in 1975 is for the 1961-1990 trend. The red symbols show trends after 1990, ending with the 1984-2013 trend. The blue symbol shows that the 1935-1990 trend was zero, and the orange symbol shows the trend from 1991 to 2013. SIE values are obtained from Walsh et al. (2015).

secutive 30-year trends are significantly different from trend periods before 1990 (Fig. 7), and thus the September ice loss since the 1990s is unprecedented as far back as 1850 (Walsh et al., 2017).

\subsection{Effects of long-term variability and trends in ice export}

Our ice export values are largely consistent with previous studies on FS ice export for the recent decades (Kwok et al., 2013; Spreen et al., 2009; Smedsrud et al., 2011). The yearto-year variability is of the same order, and the maximum and minimum values are also similar. The largest difference to the Smedsrud et al. (2011) export values is that the time series is updated to 2014 and now extends back to 1935 and the seasonal adjustment representing the EGC provides a better match with the SAR-based monthly export (Fig. 3). In addition, there is no overall long-term linear trend in annual export.

The effect of sea ice drift variability on the Arctic sea ice cover in general has been recognized for a long time (Thorndike and Colony 1982). Rigor et al. (2002) used drifting buoy data from 1979 to 1998 and found a systematic change between the 1980s and 1990s driven by the largescale atmospheric forcing. During the 1980s the Beaufort gyre was large, the ice stayed inside the Arctic Basin for several years, and FS sea ice export was low, contributing to a thicker ice cover. In the 1990s the Beaufort gyre weakened, ice drift was more directly from the Siberian coast to FS, and the FS sea ice export was higher. Our results are con- sistent with Rigor et al. (2002) in that the annual export was lower during the $1980 \mathrm{~s}\left(810000 \mathrm{~km}^{2}\right)$ than during the $1990 \mathrm{~s}$ $\left(890000 \mathrm{~km}^{2}\right)$. The overall maximum annual export in a calendar year occurred in 2012 with a value of $1176000 \mathrm{~km}^{2}$, but the second largest calendar year export occurred in 1995 $\left(1131000 \mathrm{~km}^{2}\right)$. Note that these values are a little different from those plotted in Fig. 5, which show the winter + spring export from 1 September through 31 August.

One suggested mechanism for the rapid decline in summer Arctic SIE is that a larger winter export could create a larger fraction of thin first-year ice that is more prone to melting out the following summer. In addition, first-year ice is smoother than thick and old ice and may allow for larger fractions of melt ponds during summer (Landy et al., 2015). Schröder et al. (2014) found a strong correlation between such simulated spring melt pond fractions and September Arctic SIE. However, in this study we find that the correlation between winter ice export and the following September SIE is modest $(r=-0.26$ between 1979 and 2014). Thus, the small increase in winter ice export over the last 35 years $(2.6 \%$ per decade) suggests that summer ice loss is not particularly sensitive to winter sea ice export. Because the winter export is larger than the spring export there has generally been a clear connection between annual and winter export anomalies. However, while there is little change in winter export, there has been a notable increase in the spring export. In fact, in recent years the spring export has been almost as large as the winter export (Fig. 5). An increase in summer ice export (June-September) for 2000-2010 was already noted by Kwok et al. (2013), and here we show that this is part of a longer trend. We turn our attention towards the increasing spring export in Sect. 4.5, but first examine the cause of the variability in the larger atmospheric circulation.

\subsection{Influence of large-scale atmospheric circulation}

Rigor et al. (2002) concluded that annual FS export correlated well with the Arctic Oscillation (AO) index during the 1980s and 1990s, and they found a $10 \%$ increase of FS export with an $\mathrm{AO}$ index of +1 . The response was most apparent for the winter (DJF) AO index and the winter ice export. Examining our longer time series, this relationship does not appear stationary in time, and since 2000 the AO index has fluctuated around zero, while the FS export has remained at anomalously high levels. The maximum DJF AO value occurred in 1989, not related to a peak in the annual FS export. Over the 80-year time series we find that the winter $\mathrm{AO}$ index is not a good indicator of winter FS ice export, the correlation is as low as $r=0.19$ (using DJF AO, and winter export (SONDJF), and it only increases to $r=0.22$ when the winter $\mathrm{AO}$ index is also calculated for SONDJF. This is not surprising because the $\mathrm{AO}$ spatial pattern does not exhibit strong pressure gradients in the FS (not shown). The lack of a consistent long-term relationship between FS export and the AO index is consistent with Hilmer and Jung (2000). They found 


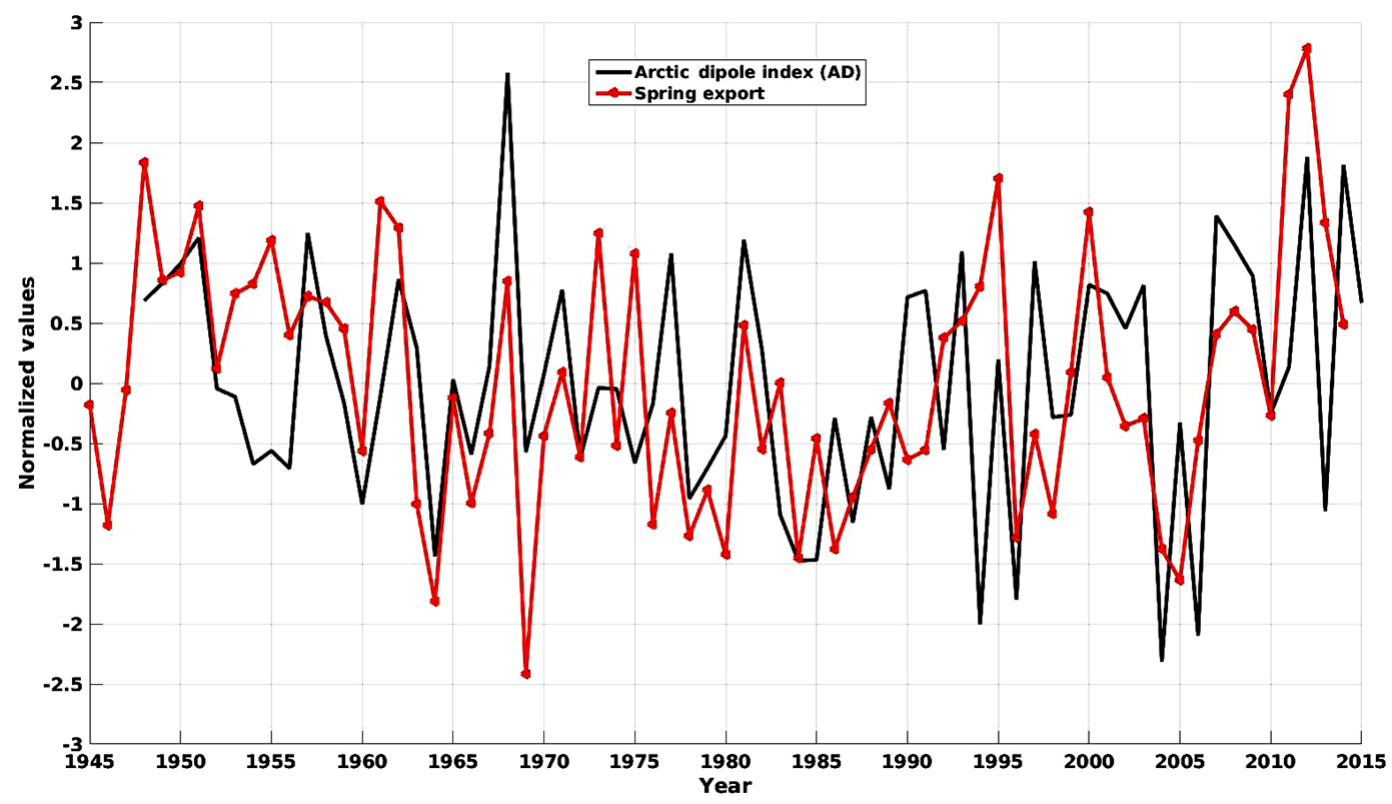

Figure 8. Fram Strait spring export (March-August) and April-July Arctic dipole (NCEP/NCAR reanalysis) anomalies from 1948 to 2014. Both time series are detrended and normalized by their standard deviations, 0.817 million $\mathrm{km}^{2}$ and $28.8 \mathrm{hPa}$, respectively. The correlation between them is $r_{\mathrm{AD}-\mathrm{FS}}$ ice export $=0.45$ for the entire period and similar for 1979-2014 $\left(r_{\mathrm{AD}-\mathrm{FS}}\right.$ ice export $\left.=0.44\right)$.

no correlation between the winter North Atlantic Oscillation index (NAO, which closely resembles the $\mathrm{AO}$ ), and winter FS ice export for the period 1958-1977, but did find higher correlations for 1978-1997, again consistent with Rigor et al. (2002).

Other studies have suggested that FS export is more strongly linked to a SLP dipole pattern than the AO (Tsukernik et al., 2010). They found that on a daily timescale the atmospheric circulation pattern responsible for the export anomalies from 1979 to 2006 was a dipole between the Barents Sea (low pressure) and Greenland (high pressure). The ice motion was maximized at $0 \mathrm{lag}$, persisted yearround, over timescales of 10-60 days. This SLP dipole pattern emerged from the second empirical orthogonal function (EOF) of daily SLP anomalies in both winter and summer, with maximum correlation east and west of the FS. An implication of this result is to use station-based observed crossstrait SLP pressure gradient like we have done here.

The observed cross-strait SLP gradient, the dipole pattern analyzed by Tsukernik et al. (2010), and the Arctic dipole (AD) are similar expressions of varying strength of the southerly winds in FS (Wu et al., 2006). The AD has been suggested previously as a major driver of the record low Arctic summer SIE in 2007 (Wang et al., 2009) and was defined as the second leading mode (PC2) of spring (AprilJuly) SLP anomalies within the Arctic Circle. In this study, we define a positive AD pattern as having a positive SLP anomaly over Greenland and a negative SLP anomaly over the Kara and Laptev seas, a pattern which enhances transpolar ice drift. We calculate the AD index onwards from 1948 using the NCEP/NCAR reanalysis data, for which data are not available before 1948. The observed AD index and spring export correlates $\left(r_{\mathrm{AD}-\mathrm{FS}}\right.$ ice export $\left.=0.45\right)$ over the longer period 1948-2014 (Fig. 8), as well as over the shorter satellite data record $\left(r_{\mathrm{AD}-\mathrm{FS}}\right.$ ice export $=0.44$ for $\left.1979-2014\right)$. These correlations suggest that the AD explains part of the FS ice export variability but that the cross-strait SLP gradient remains the best predictor of the local wind forcing and therefore FS sea ice drift. These results substantiate the results of Wu et al. (2006) that found a similar link for FS ice motion and the AD using buoy data from 1979 to 1998. In future projections, high rates of summer Arctic sea ice loss are also associated with enhanced transpolar drift and FS ice export driven by changing sea level pressure patterns (Wettstein et al., 2014). Wettstein at al. (2014) found co-varying atmospheric circulation patterns resembling the $\mathrm{AD}$, with maximum amplitude between April and July.

\subsection{High annual export during the last decade}

Our updated time series shows large annual values of Arctic sea ice export during the last decade. The same SAR-based export values used here were previously used by Smedsrud et al. (2011) for 2004-2010, but 2011, 2012, and 2013 had unreported annual exports above 1 million $\mathrm{km}^{2}$ (Fig. 5). A comparison between SAR-based and passive microwave-based drift speeds gave mostly similar values for both methods since 2007 but indicated some high export events that are only detected using the SAR-based drift speeds (Smedsrud et al., 2011). This is likely the major explanation for the dif- 
ference between previous passive microwave-based export values (Kwok, 2009) and our results. Note that Kwok et al. (2013) do find a positive trend for annual export for 20012009 , and the values are lower. We believe that the cause of the differences primarily results from the coarse resolution of the passive satellite observations missing some high-speed export events during winter. We speculate that high sea ice concentrations in the FS make it difficult to track individual sea ice floes using the coarser-resolution passive microwave images as done by Kwok et al. (2013) and note that changes in FS sea ice concentration between 1979 and 2004 do not lead to such differences in ice export (Fig. 5).

The Arctic Basin covers an area of about 7.8 million $\mathrm{km}^{2}$ and has been fully ice covered from November through May since 1979. The annual ice export during the $1980 \mathrm{~s}$ $\left(\sim 800000 \mathrm{~km}^{2}\right)$ was $10 \%$ of this winter ice-covered area. However, during the last 7 years (2007-2014) the mean annual ice export increased to nearly 1 million $\mathrm{km}^{2}$, representing $13 \%$ of this area. This is the relative ice export, or the large-scale divergence of the Arctic Basin sea ice cover: the export divided by the area covered by sea ice.

If the sea ice cover decreases and the export remains constant, the divergence, or the relative export, increases too. The observed increase in export represents a $30 \%$ increase in the relative area export, but with a smaller annual mean ice-covered area inside the Arctic Basin the increase rises to about $40 \%$. This value is based on using a 1 million $\mathrm{km}^{2}$ export and a mean annual ice-covered area inside the Arctic Basin of 7.0 million $\mathrm{km}^{2}$ for the last 7 years (2007-2014). Such an increase in export is expected to contribute towards both a thinner and smaller Arctic ice cover in general (Langehaug et al., 2013), because older and thicker sea ice than the Arctic Basin average is transported southward through FS. During winter, the open water anomalies created within the basin quickly refreeze, and thus an impact of the modestly increased winter ice export since 1979 has likely been towards a thinner ice cover (Lindsay and Schweiger, 2016). This is consistent with Fučkar et al. (2015) who found that a reduction of the FS winter export related to their CanadianSiberian dipole cluster explains a thickening over most of the Arctic Basin between 0.2 and $0.5 \mathrm{~m}$. This cluster is the one with the largest change in FS export and explains $28.6 \%$ of the variability, while the other two clusters mostly describe divergence within the basin. Williams et al. (2016) recently found a clear link between FS area export anomalies and September SIE ( $r=0.72)$ for the years 1993-2014 and that export anomalies from February until June contributed to the following September SIE. We therefore proceed with a discussion of the spring export that has increased since 1979.

\subsection{Consequences of spring Fram Strait ice export anomalies}

The later in the season the export anomaly occurs, the stronger effect one might expect on the September minimum
Table 1. Correlations over time between Fram Strait spring export and mid-September sea ice extent $\left(r_{\mathrm{FS}}\right.$ ice export-Sept SIE).

\begin{tabular}{lrrrr}
\hline & $1935-2014$ & $1979-2014$ & $1993-2014$ & $2004-2014$ \\
\hline Export and extent & -0.23 & -0.55 & -0.49 & -0.72 \\
Detrended values & -0.43 & -0.39 & -0.47 & -0.74 \\
\hline
\end{tabular}

SIE. However, working against this is the overall decrease in export from March towards August (Fig. 4). However, even if there is some regrowth in March, April, and May from increased spring export, the newly formed ice will be thin and have a thin snow cover and therefore likely melt more easily and deform later the same season. The transition from winter and refreezing to summer and positive ice-albedo feedback occurs gradually later in the year as one moves north, but melting will prevail over most of the Arctic Basin onwards from May (Markus et al., 2009). Williams et al. (2016) found that FS export anomalies are a better predictor for the September SIE than coastal divergence between 1993 and 2014. This was caused by the ice export being a good estimate also for the net perennial pack ice divergence. Our results confirm their findings for the last 2 decades, but we also find a more moderate link for the entire 80 -year period. For the recent 10 years (2004-2014), when our ice export values are directly observed by SAR the detrended anticorrelation is $r_{\mathrm{FS}}$ ice export-Sept SIE $=-0.74$ (Table 1 ), similar to Williams et al. (2016). For the last 20 years we get a more modest influence $(r=-0.47)$, and for the entire 80-year period we get $r=-0.43$ (Table 1). The explained general variance is thus in the range $15-20 \%$.

The increase in spring FS ice export from the 1980s to 2010 was on the order of $200000 \mathrm{~km}^{2}$ (Fig. 5). Meanwhile the September SIE decreased by about 2.0 million $\mathrm{km}^{2}$ (Fig. 6). It is thus a similar magnitude of influence, about $10 \%$, between the direct change in spring FS ice export compared to the anomalies in September SIE themselves, as found based on the anticorrelations in Table 1.

Any perturbations in Arctic sea ice cover may be further enhanced by positive feedback mechanisms. Two strong positive feedbacks that enhance summer ice loss are the icealbedo feedback (Perovich et al., 2007) and the smaller resistance of thinner ice to wind-driven ridging (Rampal et al., 2009; Hutchings and Perovich, 2015). Since 1979, melt onset has also begun about 10 days earlier than it used to inside the Arctic Basin, allowing for earlier development of open water (Stroeve et al., 2014). Using observed solar forcing from the North Pole stations (Björk and Söderkvist, 2002) and representative change in surface albedo and open water area (Perovich et al., 2007), we estimate that an additional ice area exported during spring (March-August) of $200000 \mathrm{~km}^{2}$ can lead to melting of about $400000 \mathrm{~km}^{2}$ of a $1.5 \mathrm{~m}$ thick sea ice cover (Zygmuntowska et al., 2014). The ice-albedo feedback thus has the potential to increase initial open water 
areas to a total of $600000 \mathrm{~km}^{2}$ or explain about $25 \%$ of the total 2.5 million $\mathrm{km}^{2}$ loss of September SIE since the 1980s.

\subsection{Other drivers of September sea ice extent variability}

Finally, a large number of processes have likely contributed to the September SIE variability over the last 80 years. Among these are advection of heat towards the Arctic in the ocean and the atmosphere, sea ice divergence within the Arctic Ocean, increased greenhouse gases of the atmosphere, and also changes in sea ice export. From the above discussion the influence from ice export appears to be generally between 10 and $20 \%$. For individual years like 2007, sea ice divergence is found to be an important factor (Hutchings and Perovich, 2015), while the influence from atmospheric and oceanic heat transport is further discussed below.

Using coupled climate model simulations, Zhang (2015) identified the northward Atlantic heat transport, Pacific heat transport, and the spring $\mathrm{AD}$ as the main predictors of lowfrequency variability of summer Arctic SIE. The study focused on variability longer than 30 years and used a 3600 year segment of the preindustrial control simulation from the Geophysical Fluid Dynamics Laboratory (GFDL) Coupled Model version 2.1 (CM2.1). The influence of oceanic heat transport is smaller for the year-to-year variability that we focus on in this paper, leaving the $\mathrm{AD}$ as one of the main causes of simulated summer Arctic SIE variability at the interannual timescale.

Using the same 3600-year-long GFDL CM2.1 control simulation, we find that the simulated spring FS ice export is indeed significantly inversely correlated with the September SIE $(r=-0.34)$ and positively correlated with the AD index $(r=0.63$, not shown). This is similar to the inverse correlation found between the observed detrended spring FS ice export and September SIE over the 80 years from 1935 to 2014 ( $r=-0.43$, Table 1$)$ and supports a general level of influence from the spring FS ice export of around $10 \%$ on the observed September SIE loss. The link between the AD and spring FS ice export appears stronger in model simulations than for the available observations $\left(r_{\mathrm{AD}-\mathrm{FS}}\right.$ ice export $\left.=0.45\right)$ between 1948 and 2014.

The simulations in Zhang (2015) suggested the AD to be one of the main drivers of low-frequency summer Arctic SIE. Here we would like to estimate how much of this $\mathrm{AD}$ influence can be explained by FS ice export at the interannual timescale from observed correlations since 1979 . In this period $r_{\mathrm{AD}-\mathrm{Sept}} \mathrm{SIE}=-0.53$. We roughly estimate that $45 \%$ of this correlation is caused indirectly by the FS spring export variability, because $r=r_{\text {AD-FS ice export }} \times r_{\mathrm{FS}}$ ice export-Sept SIE $=0.44 \times$ $-0.54=-0.24$, and $(-0.24) /(-0.53)=0.45$. The FS spring export and the AD therefore have roughly equal contributions to September SIE variability in addition to the common mechanism being stronger northerly geostrophic winds driving higher spring export. The additional direct $\mathrm{AD}$ influence on summer Arctic SIE is probably due to ridging inside the Arctic Basin and atmospheric advection of heat and moisture (Graversen et al., 2011). The FS export influence independent from the $\mathrm{AD}$ is plainly export variability not driven by AD.

We also examined a forced historical simulation for the 20 th century combined with a forced 21 th century projection under the Coupled Model Intercomparison Project phase 3 (CMIP3) A1B scenario using the GFDL model. In these simulations we found no significant trend in simulated spring FS ice export between 1979 and 2013. We thus suggest further studies on the role of FS export anomalies using dedicated numerical simulations.

\section{Conclusions}

A new and updated time series of Fram Strait ice area export from 1935 to 2014 was presented in this study. The new time series was constructed using high-resolution radar satellite imagery of sea ice drift across $79^{\circ} \mathrm{N}$ from 2004 to 2014, regressed on the observed cross-strait surface pressure difference back to 1935 . The overall long-term mean annual export is $883000 \mathrm{~km}^{2}$, and there are no significant trends over this 80 -year record. Winter export (September-February) carries about $60 \%$ of the annual export, while the spring export (March-August) carries the remaining $40 \%$.

The pressure difference from observed sea level pressure across the Fram Strait on Svalbard and Greenland directly explains $53 \%$ of the variance in the observed ice export for 2004-2014. The best fit between ice drift and geostrophic winds results in a seasonal difference of $\sim 3 \mathrm{~cm} \mathrm{~s}^{-1}$, suggesting that the East Greenland Current, carrying a large part of the export, flows faster during winter and slower during summer, consistent with generally stronger large-scale or thermal wind forcing. The ice export based on observed sea level pressure, including a seasonal variation in the underlying current, explains almost $80 \%$ of the observed ice export variance.

While there are no long-term trends in export from 1935 to 2014, we do find positive and robust trends in sea ice area export over the last 35 years. This increase in export is created by stronger geostrophic winds, largely due to an observed increase in the surface pressure on Greenland, creating a positive trend of $+6 \%$ per decade for annual mean ice area export since 1979 (Fig. 5). The trend is mostly explained by the high trends for spring and summer months (March-August), when ice export has a robust trend of $+11 \%$ per decade. These seasonal values of ice export since 1979 are not sensitive to changes in Fram Strait sea ice concentration from Walsh et al. (2015), but the ice export in the 1950s may have been higher because of higher sea ice concentration during winter and summer then. 
Despite not explaining all of the variance in ice export, the surface pressure-based time series suggest that about $18 \%$ of the observed variance in September sea ice extent is explained by spring ice export through Fram Strait between 1935 and 2014. The remaining $82 \%$ of the variance would be caused by a large number of other processes, such as changes in ocean stratification and heat transport (Zhang, 2015), cloud cover (Francis et al., 2005), atmospheric heat transport (Graversen et al., 2011), and wind-driven ridging (Hutchings and Perovich, 2015). We have confidence in the moderate contribution from the Fram Strait export because it is a physical process, and the results are similar to simulations partially explaining the correlation between the observed AD anomalies and the September SIE (Zhang 2015). This is simply the wind forcing (AD) driving the ice export, again leading to anomalies in September SIE. Onwards from the 1990s, the covariance between Fram Strait spring ice area export and September SIE increases, consistent with the results from Williams et al. (2016). Between 1993 and 2014, $22 \%$ of the observed variance in mid-September sea ice extent is explained by the spring ice export, increasing to $55 \%$ for the last 10 years (Table 1). To reach such a level of influence, feedbacks or other processes like ridging inside the basin and related coastal divergence have likely contributed and been correlated with the export anomalies (Williams et al., 2016). Positive feedback mechanisms enhancing summer SIE anomalies are the ice-albedo feedback and increased deformation of thinner ice (Perovich et al., 2007; Rampal et al., 2009).

During the last 10-20 years, the Arctic sea ice cover has decreased quite rapidly, and the contributions from natural variability and greenhouse gas forcing are still being debated. We calculated an important driver of Arctic sea ice variability for the last 80 years and found that over this timescale there is no systematic increase in sea ice area exported southwards out of the Arctic Ocean in the Fram Strait. This is consistent with available historical simulations stating that we do not expect any systematic ice export change related to global warming (Langehaug et al., 2013). This is also consistent with studies stating that there is little systematic change in the Arctic large-scale circulation (Vihma, 2014). The Arctic ice cover is now thinner and more mobile than before, and over the last 3 decades the coupling between September ice cover and the Fram Strait spring sea ice area export has increased. The increased export over the last 35 years appears to be linked to natural variability on multi-decadal timescales because there is no trend over the last 80 years. Such a longterm variability has been found in northern hemispheric surface air temperature and temperature of inflowing Atlantic water to the Barents Sea (Smedsrud et al., 2013). Consequently we speculate that there may be potential for a partial recovery of the September SIE in the next decade or two, when, or if, the spring ice export decreases back to the longterm mean level of the last 80 years.

\section{Data availability}

The monthly mean 80-year time series of ice export is available here: doi:10.1594/PANGAEA.868944.

Author contributions. Mari H. Halvorsen did most of the calculations of sea ice export based on the sea level pressure data, Julienne C. Stroeve calculated and plotted sea ice extent variations and helped refocus the manuscript, Rong Zhang contributed with analyzing the Arctic dipole time series and simulated sea ice export, and Kjell Kloster analyzed the original SAR images and calculated monthly mean ice speed and export. Lars H. Smedsrud prepared the manuscript with contributions from all co-authors and made most of the figures.

Acknowledgement. Sea ice drift data were obtained from Kloster and Sandven (2015), where ScanSAR data were provided by Norwegian Space Centre and Kongsberg Satellite Service under the Norwegian-Canadian Radarsat agreements 2012-2014. Observed pressure data are from the Norwegian and Danish meteorological institutes. The observed Arctic dipole index is derived from the NCEP/NCAR reanalysis. Mari H. Halvorsen was supported by the Geophysical Institute at the University of Bergen, Lars H. Smedsrud by the BASIC project in the Centre for Climate Dynamics (SKD) and the ice2ice project (ERC grant 610055) from the European Community's Seventh Framework Programme (FP7/2007-2013), and Julienne C. Stroeve by NASA Award NNX11AF44G. We would like to thank Tor Gammelsrød, our editor Jennifer Hutchings, and the anonymous reviewers for helpful comments.

Edited by: J. Hutchings

Reviewed by: two anonymous referees

\section{References}

Björk, G. and Söderkvist, J.: Dependence of the Arctic Ocean ice thickness distribution on the poleward energy flux in the atmosphere, J. Geophys. Res.-Oceans, 107, 3173, doi:10.1029/2000JC000723, 2002.

Cappelen, J.: Weather observations from Greenland 1958-2013, Observation data with description, Tech. Rep., DMI Technical Report 14-08, Danish Meteorological Institute, Copenhagen, 2014.

Chapman, W. L. and Walsh, J. E.: Arctic and Southern Ocean Sea Ice Concentrations, Boulder, Colorado USA: National Snow and Ice Data Center, doi:10.7265/N5057CVT (last access: 20 January 1996), 1991.

Comiso, J. C.: Large decadal decline of the Arctic multiyear ice cover, J. Clim., 25, 1176-1193, 2012.

Daniault, N., Mercier, H., and Lherminier, P.: The 1992-2009 transport variability of the East Greenland-Irminger Current at $60^{\circ} \mathrm{N}$, Geophys. Res. Lett., 38, L07601, doi:10.1029/2011GL046863, 2011. 
de Steur, L., Hansen, E., Mauritzen, C., Beszczynska-Möller, A., and Fahrbach, E.: Impact of recirculation on the East Greenland Current in Fram Strait: Results from moored current meter measurements between 1997 and 2009, Deep-Sea Res. Pt. I, 92, 2640, 2014.

Francis, J. A., Hunter, E., Key, J. R., and Wang X.: Clues to variability in Arctic minimum sea ice extent, Geophys. Res. Lett., 32, L21501, doi:10.1029/2005GL024376, 2005.

Fučkar, A., Guemas, V., Johnson, N. C., Massonnet, F., and Doblas-Reyes, F. J.: Clusters of interannual sea ice variability in the northern hemisphere, Clim. Dynam., 47, 1527-1543, doi:10.1007/s00382-015-2917-2, 2016.

Graversen, R. G., Mauritsen, T., Drijfhout, S., Tjernström, M., and Mårtensson, S.: Warm winds from the Pacific caused extensive Arctic sea-ice melt in summer 2007, Clim. Dynam., 36, 11-12, doi:10.1007/s00382-010-0809-z, 2103-2112, 2011.

Hakkinen, S., Proshutinsky, A., and Ashik, I.: Sea ice drift in the Arctic since the 1950s, Geophys. Res. Lett., 35, L19704, doi:10.1029/2008GL034791, 2008.

Hansen, E., Gerland, S., Granskog, M., Pavlova, O., Renner, A., Haapala, J., Løyning, T., and Tschudi, M.: Thinning of Arctic sea ice observed in Fram Strait: 1990-2011, J. Geophys. Res.Oceans, 118, 5202-5221, doi:10.1002/jgrc.20393, 2013.

Hilmer, M. and Jung, T.: Evidence for a recent change in the link between the North Atlantic Oscillation and Arctic sea ice export, Geophys. Res. Lett., 27, 989-992, 2000.

Hutchings, J. K. and Perovich, D. K.: Preconditioning of the 2007 sea-ice melt in the eastern Beaufort Sea, Arctic Ocean, Ann. Glaciol., 56, 94-98, doi:10.3189/2015AoG69A006, 2015.

Isachsen, P. E., La Casce, J., Mauritzen, C., and Häkkinen, S.: Wind driven variability of the large-scale recirculating flow in the Nordic Seas and Arctic Ocean, J. Phys. Oceanogr., 33, 25342550, 2003.

Kay, J. E., Holland, M. M., and Jahn, A.: Inter-annual to multidecadal Arctic sea ice extent trends in a warming world, Geophys. Res. Lett., 38, L15708, doi:10.1029/2011GL048008, 2011.

Kloster, K. and Sandven, S.: Ice Motion and Ice Area Flux in the Fram Strait at 79-81N, Technical Report, 322d, Nansen Environmental and Remote Sensing Center, Bergen, Norway, https://www.nersc.no/sites/www.nersc.no/files/ NERSC-TecRep-322d(2015).pdf, 2015.

Krumpen, T., Gerdes, R., Haas, C., Hendricks, S., Herber, A., Selyuzhenok, V., Smedsrud, L., and Spreen, G.: Recent summer sea ice thickness surveys in Fram Strait and associated ice volume fluxes, The Cryosphere, 10, 523-534, doi:10.5194/tc-10523-2016, 2016

Kwok, R.: Outflow of Arctic Ocean sea ice into the Greenland and Barents Seas: 1979-2007, J. Clim., 22, 2438-2457, 2009.

Kwok, R. and Cunningham, G. F.: Contribution of melt in the Beaufort Sea to the decline in Arctic multiyear sea ice coverage: 1993-2009, Geophys. Res. Lett., 37, L20501, doi:10.1029/2010GL044678, 2010.

Kwok, R., Spreen, G., and Pang, S.: Arctic sea ice circulation and drift speed: Decadal trends and ocean currents, J. Geophys. Res.Oceans, 118, 2408-2425, 2013.

Landy, J. C., Ehn, J. K., and Barber, D. G.: Albedo feedback enhanced by smoother Arctic sea ice, Geophys. Res. Lett., 42, 10714-10720, doi:10.1002/2015GL066712, 2015.
Langehaug, H. R., Geyer, F., Smedsrud, L. H., and Gao, Y.: Arctic sea ice decline and ice export in the CMIP5 historical simulations, Ocean Model., 71, 114-126, doi:10.1016/j.ocemod.2012.12.006, 2013.

Lindsay, R. and Schweiger, A.: Arctic sea ice thickness loss determined using subsurface, aircraft, and satellite observations, The Cryosphere, 9, 269-283, doi:10.5194/tc-9-269-2015, 2015.

Markus, T., Stroeve, J. C., and Miller, J.: Recent changes in Arctic sea ice melt onset, freezeup, and melt season length, J. Geophys. Res., 114, C12024, doi:10.1029/2009JC005436, 2009.

Nghiem, S., Rigor, I., Perovich, D., Clemente-Colón, P., Weatherly, J., and Neumann, G.: Rapid reduction of Arctic perennial sea ice, Geophys. Res. Lett., 34, L19504, doi:10.1029/2007GL031138, 2007.

Perovich, D. K., Light, B., Eicken, H., Jones, K. F., Runciman, K., and Nghiem, S. V.: Increasing solar heating of the Arctic Ocean and adjacent seas, 1979-2005: Attribution and role in the icealbedo feedback, Geophys. Res. Lett., 34, L19505, doi:10.1029/2007GL031480, 2007.

Rampal, P., Weiss, J., and Marsan, D.: Positive trend in the mean speed and deformation rate of Arctic sea ice, 1979-2007, J. Geophys. Res., 114, C05013, doi:10.1029/2008JC005066, 2009.

Rigor, I. G., Wallace, J. M., and Colony, R. L.: Response of Sea Ice to the Arctic Oscillation, J. Clim., 15, 2648-2663, 2002.

Schröder, D., Feltham, D. L., Flocco, D., and Tsamados, M.: September Arctic sea-ice minimum predicted by spring meltpond fraction, Nature Climate Change, 4, 353-357, 2014.

Serreze, M. C., Barrett, A. P., Slater, A. J., Steele, M., Zhang, J., and Trenberth, K. E.: The large-scale energy budget of the Arctic, J. Geophys. Res., 112, D11122, doi:10.1029/2006JD008230, 2007.

Smedsrud, L. H., Sirevaag, A., Kloster, K., Sorteberg, A., and Sandven, S.: Recent wind driven high sea ice area export in the Fram Strait contributes to Arctic sea ice decline, The Cryosphere, 5, 821-829, doi:10.5194/tc-5-821-2011, 2011.

Smedsrud, L. H., Esau, I., Ingvaldsen, R.B., Eldevik, T., Haugan, P.M., Li, C., Lien, V. S., Olsen, A., Omar, A. M., Otterå, O. H., Risebrobakken, B., Sand $\varnothing$, A. B., Semenov, V. A., and Sorokina, S. A.: The role of the Barents Sea in the Arctic climate system, Rev. Geophys., 51, 415-449, doi:10.1002/rog.20017, 2013.

Spreen, G., Kern, S., Stammer, D., and Hansen, E.: Fram Strait sea ice volume export estimated between 2003 and 2008 from satellite data, Geophys. Res. Lett., 36, L19502, doi:10.1029/2009GL039591, 2009.

Spreen, G., Kwok, R., and Menemenlis, D.: Trends in Arctic sea ice drift and role of wind forcing: 1992-2009, Geophys. Res. Lett., 38, L19502, doi:10.1029/2009GL039591, 2011.

Stroeve, J. C., Kattsov, V., Barrett, A., Serreze, M., Pavlova, T., Holland, M., and Meier, W. N.: Trends in Arctic sea ice extent from CMIP5, CMIP3 and observations, Geoph. Res. Lett., 39, L16502, doi:10.1029/2012GL052676, 2012.

Stroeve, J. C., Markus, T., Boisvert, L., Miller J., and Barrett, A.: Changes in Arctic melt season and implications for sea ice loss, Geophys. Res. Lett., 41, 1216-1225, doi:10.1002/2013GL058951, 2014.

Stroeve, J. C. and Notz, D.: Insights on past and future sea-ice evolution from combining observations and models, Glob. Planet. Change 135, 119-132, doi:10.1016/j.gloplacha.2015.10.011, 2015. 
Thorndike, A. and Colony, R.: Sea ice motion in response to geostrophic winds, J. Geophys. Res.-Oceans, 87, 5845-5852, 1982.

Tsukernik, M., Deser, C., Alexander M., and Tomas, R.: Atmospheric forcing of Fram Strait sea ice export: a closer look, Clim. Dynam., 35, 1349-1360, doi:10.1007/s00382-009-0647-z, 2010.

van Angelen, J. H., van den Broeke, M. R., and Kwok, R.: The Greenland Sea Jet: A mechanism for wind-driven sea ice export through Fram Strait, Geophys. Res. Lett., 38, L12805, doi:10.1029/2011GL047837, 2011.

Vihma, T.: Effects of Arctic Sea Ice Decline on Weather and Climate: A Review, Surv. Geophys., 35, 1175-1214, doi:10.1007/s10712-014-9284-0, 2014.

Walsh, J. E., Chapman, W. L., and Fetterer, F.: Gridded monthly sea ice extent and concentration, 1850 onwards, Boulder, Colorado USA, National Snow and Ice Data Center, Digital media, 2015.

Walsh, J. E., Fetterer, F., Scott Stewart, J., and Chapman, W. L.: A database for depicting Arctic sea ice variations back to $1850, \mathrm{Ge}-$ ogr. Rev., 107, 89-107, doi:10.1111/j.1931-0846.2016.12195.x, 2017.

Wang, J., Zhang, J., Watanabe, E., Ikeda, M., Mizobata, K., Walsh, J. E., Bai, X., and Wu, B.: Is the Dipole Anomaly a major driver to record lows in Arctic summer sea ice extent?, Geophys. Res. Lett., 36, L05706, doi:10.1029/2008GL036706, 2009.
Wettstein, J. J. and Deser, C.: Internal variability in projections of twenty-first-century Arctic sea ice loss: Role of the large-scale atmospheric circulation, J. Clim., 27, 527-550, 2014.

Widell, K., Østerhus, S., and Gammelsrød, T.: Sea ice velocity in the Fram Strait monitored by moored instruments, Geophys. Res. Lett., 30, 1982, doi:10.1029/2003GL018119, 2003.

Williams, J. Tremblay, B., and Newton, R.: Dynamic preconditioning of the September sea-ice extent minimum, J. Clim., 29, 58795891, doi:10.1175/JCLI-D-15-0515.1, 2016.

Wu, B., Wang, J., and Walsh, J. E.: Dipole anomaly in the winter Arctic atmosphere and its association with sea ice motion, J. Clim., 19, 210-225, 2016.

Zhang, R.: Mechanisms for low-frequency variability of summer Arctic sea ice extent, P. Natl. Acad. Sci. USA, 112, 4570-4575, 2015.

Zwally, H. J. and Gloersen, P.: Arctic sea ice surviving the summer melt: interannual variability and decreasing trend, J. Glaciol., 54, 279-296, 2008.

Zygmuntowska, M., Rampal, P., Ivanova, N., and Smedsrud, L. H.: Uncertainties in Arctic sea ice thickness and volume: new estimates and implications for trends, The Cryosphere, 8, 705-720, doi:10.5194/tc-8-705-2014, 2014. 